\title{
The Influence of Housing Attributes on Housing Price in East Surabaya
}

\author{
Kresno Eka Mukti \\ Laboratorium Pengembangan Ekonomi Pembangunan \\ Faculty of Economics and Business, Universitas Airlangga \\ Surabaya, Indonesia \\ kresnokresno@yahoo.com
}

\begin{abstract}
The emerging middle class in Indonesia at the moment have some potentials to be the largest consumers in housing sector which is middle class housing. The phenomenon happens in East Surabaya, even further after the opening access of Middle East Ring Road (MERR). Before buying a house, households make a bid based on their valuation of the housing attributes: physical attributes and neighborhood characteristics. However, developers usually cannot make exact calculation about the influences of those attributes on the housing price; causes the offered housing price is not optimal. The objective of this research is to identify the influence of housing attributes toward middle class housing price in East Surabaya.
\end{abstract}

The respondents are society who bought middle class house in the period of 2011-2015. The data were collected by doing structured interviews with 100 respondents. This research uses multiple regression method in data processing.

This research found that seven house attributes simultaneously influence significantly the housing price. The most significant housing attribute in affecting the housing price is the number of bedroom.

This research is useful for housing developers, as it shows the influence of housing attributes towards housing price on consumers' perspective. In addition, hopefully, this research will be able to help the developers in calculating the middle housing price based on housing characteristics by consumers' perspective

Keywords-Household's valuation, housing attributes, housing price, middle class housing

\section{INTRODUCTION}

Bank of Indonesia (BI) stated that middle class housing sale had the highest growth compared to other housing types, by $33,6 \%$ in first quarter of 2013 [1]. Executive Director of Bank Indonesia Communication Department at the time, Difi Johansyah, said that the growth was influenced by middle-class society growth.

The phenomenon also happened in Surabaya, especially East Surabaya. Former Chairman of REI (Real Estate Indonesia) of East Java, Erlangga Satriagung, said that the sale growth of middle class housing was also influenced by the access of Middle East Ring Road opened in East Surabaya.
As household, buying a house is considered as the greatest expense. Therefore, the housing price is the main consideration for them [2]. For housing product, the consideration means a valuation process toward housing attributes that they are about to buy [3]. In general, the housing attributes which are estimated to be able to influence the housing price are physical attributes and neighborhood characteristics/ location [4].

The housing price is obtained by the process of negotiations between household (buyer) and developer (seller). Households make a bid based on their valuation of the housing attributes [5]. However, developers usually do not analyze customers' preference for deciding the price of houses they sell. They refer to their experience in selling the similar products; the calculation and assumption are without any scientific research. It causes optimal price cannot be offered. It concludes that there is difference between developers and households in housing price perception [6]. Moreover, developers in general are not able to make exact calculation of the influences of neighborhood characteristics (such as distance from CBD, distance from school, etc) on the housing price, says Wirastuti, general manager of Citra Garden Sidoarjo Housing. In other words, in general, developers cannot calculate empirically some changes of housing attributes or variation of housing attributes such as "How much is additional price of house for each kilometer further to CBD?". It is similar to the statement of [3] stating that the price of each attribute is never directly calculated in housing marketing. Whereas, neighborhood characteristics is the attribute calculated by household before they decided to buy [5].

It is important to observe the influence of middle class housing attributes on middle class housing price in Surabaya. The result of this research, hopefully will be able to help housing developers in setting the middle class housing prices. Besides, as the second biggest city in Indonesia, Surabaya can be the model reference of housing prices for other big cities in Indonesia.

\section{LITERATURE REVIEW}

There have been many theories and researches about the influences of housing attributes on the housing price. Those researches studied different housing attributes although there are some researches studying the same/ similar housing attributes. Unfortunately, only few attributes can be studied in 
Surabaya, considering some differences of housing characteristics and the respondents' culture compared to other researches. Therefore, this research needs references from previous relevant researches studying the housing attributes. Some previous researches can be used as references in order to get the housing attributes suitable to this research. McDonald and McMillen (2007) [5] said that customers would have not considered all housing attributes before they bought a house. Therefore, it is recommended to limit attributes or variables to value a house.

These are similar researches which can be used as references: [7], [8], [9], [10], and [4]. However, tight selection for variables is needed.

Cebula (2009) [7] studied about the influences of housing attributes in historical city, Savannah, Georgia. Variables used were amount of bathroom, amount of fireplaces, brick usage for wall building, availability of verandas, availability of yards, availability of basement sprinkler system, the number of storeys, exterior condition (stuccoed or not), garage width, availability of pool, the age of house structure, nearness to the park, the location (at the corner or not) (at no-through lane or not) (near lake, river, or not) (2-block away from apartment complex or not) (around congested area in Savannah or not), the time of offer closing (in may, june, or july) house status (national historic building or not) [7].

Ottensmann (2008) [8] studied the influences of housing attributes on the housing price, especially attributes of distance and duration from home to office in CBD. The variables are: amount of bathroom, amount of rooms, building width, basement availability, age of the building, garage availability, veranda availability, materials for exterior (using brick or not), availability of Air Conditioner, value of Effective Tax Rate, average of school test score in neighborhood, median of people's income, percentage of black race, percentage of vacant homes, location (located at downtown or not), and distance to CBD [8].

Bayuprima (2015) [9] studied the influence of public facilities in housing toward housing price in Magupura area. Variables used are: availability of road, availability of PDAM, availability of sewage works, availability of rain water processing, availability of waste disposal system, availability of electricity power, availability of telephone network, accessibility of public transportation [9].

Asmawi, et al (2014) [10] studied the influences of public green space in city toward the housing price in Malaysia. The variable used is availability of greening sites [10].

Wen, et al (2014) [4] studied the influences of the distance of education facilities on the house price in China. The variable used is the distance from home to various education facilities [4].

From those housing attributes, the most used attributes in researches are the amount of bathrooms, amount of rooms, age of the house, availability or width of garage, and availability of veranda. From the attributes mentioned above, the most relevant attributes to be studied in this research are amount of rooms and amount of bedrooms. Age of the house is not relevant to this issue as buyers now have to make indent to buy houses from developers. The houses will be built after the transaction is done. It means, the customers will have new built houses. Availability of garage and veranda are not relevant because this research studies middle class housing featuring one floor and no garage (carport only). Therefore, the availability of garage and veranda and the age of house are not used in this study.

The next step is to select the variables studied in this research by identifying the influential attributes on the house price. These are the influential attributes to the house price in each previous research:

1. Cebula (2009) [7]: amount of bathrooms, amount of rooms, building width, amount of fireplaces, the number of storeys, availability of yard, availability of pool, exterior condition (stuccoed or not), and availability of underground sprinkler system

2. Ottensmann (2008) [8]: amount of bathroom, availability of basement, availability of air conditioner, the average of school test score, distance to CBD.

3. Bayuprima (2015) [9]: road width in housing.

4. Asmawi, et al (2014) [10]: availability of public green space in cities.

5. Wen, et al (2014) [4]: distance from home to education facilities.

The irrelevant attributes of those researches are: amount of fireplaces, the number of storeys, availability of yard, availability of pool, exterior condition (stuccoed or not), availability of underground sprinkler system, availability of basement, and availability of air conditioner because middle class housings owned by respondents do not have those attributes. In addition, availability of yard and exterior condition are not relevant because every middle class housing in Indonesia has these attributes.

The remaining attributes are amount of bathrooms, amount of rooms, building width, road width in housing, distance to CBD, availability of public green space in cities, and distance from home to education facilities. Previous researches stated that the distance to CBD and availability of public green space in cities did not significantly influence the house price. However, some experts like Henderson in [11] and [12] stated that the distance from home to CBD positively influenced the house price. Guntoro (2011) [13] stated that green housing made high demand by society in West Surabaya. Therefore, the nine remaining attributes can be used as variables in this research.

As stated before, housing attributes which influence housing price consist of two kinds: physical attributes and neighbourhood characteristics (note that attribute location is considered as neighborhood characteristics, where the location of the house could reflect the neighborhood characteristics). When that two kinds of attributes are linked with seven attributes selected of previous researches, those seven attributes are then categorized as physical attributes (building width, amount of rooms, and amount of bathrooms) and neighbourhood characteristics (availability of public green space, road width in housing, distance from home to CBD, and distance from home to education facilities). Therefore, the seven housing attributes or research variables are used as the 
indicators of the two groups of housing attributes which seen in Table 1 below:

Table 1. Variables and Research Indicators

\begin{tabular}{|c|c|}
\hline Variable & Indicator \\
\hline \multirow{3}{*}{$\begin{array}{c}\text { Physical } \\
\text { Attributes }\end{array}$} & Building width \\
\cline { 2 - 2 } & Amount of rooms \\
\cline { 2 - 2 } Amount of bathrooms \\
\hline \multirow{3}{*}{$\begin{array}{c}\text { Neighbor } \\
\text { hood } \\
\text { stics }\end{array}$} & $\begin{array}{c}\text { Availability of public } \\
\text { green space }\end{array}$ \\
\cline { 2 - 2 } & $\begin{array}{c}\text { Road width in } \\
\text { Housing }\end{array}$ \\
\cline { 2 - 2 } & Distance from home \\
& Distance CBD \\
\hline & to education facilities \\
\hline
\end{tabular}

\section{METHODOLOGY}

The objective of this research is to identify the influences of housing attributes and their various values on the price of middle class housing in East Surabaya. The important thing is that the research studies the influences of housing attributes on the household's point of view.

This research consists of independent and dependent variables. The independent variables are the two types of house attributes: physical attributes and neighborhood characteristics as stated in Table 1 above; while the dependent variable is the price of middle class housing in East Surabaya. The housing price is the amount of money used in transaction between households and developers agreed by both of them; the transaction is done based on that price.

The population of the research is customers of middle class houses (type 36-70, single storey house) in East Surabaya, the attributes are built by developers, not by the buyers, and the houses were bought in 2011-2015.

The population of the research is located in East Surabaya; and there are approximately 2200s middle class houses in 13 housings. They are Sukolilo Dian Regency 2 and City Home Regency, Grand Semanggi Residence, Green Semanggi Mangrove, Green Lake, Citra Medayu Residence, Taman Rivera, Puri Gunung Anyar Regency, Puri Jimbaran Regency, Sentra Point, Tira Medayu, Pesona Alam Gunung Anyar, and Gunung Anyar Permai Regency.

From that population, respondents were selected by using purposive sampling technique. The number of sample of this research is determined by using this following Slovin Formula [14]:

$$
n=\frac{N}{1+N e^{2}}
$$

$\mathrm{n}$ : The number of sample

$\mathrm{N}$ : The number of population

e : Expected Critic value of s (accurateness limit), in other words percentage of inaccurateness concession because of sampling error

The critic value of this research is $10 \%$. Based on Slovin Formula, it was found the minimum number of sample needed is 96 respondents. However, this research involved 100 respondents.

From those 13 housings, only eight housings were selected; they are: City Home Regency, Grand Semanggi Residence, Green Semanggi Mangrove, Green Lake, Citra Medayu Residence, Puri Gunung Anyar Regency, Pesona Alam Gunung Anyar, and Gunung Anyar Permai Regency. The selection considered the ease of getting permission to conduct the survey and efficiency in conducting the survey.

The data were conducted through structured interview to respondents and observation on the housing attributes. Respondents were interviewed about their housing attributes (building width, amount of room, amount of bathroom, and the availability of public green space) and housing price when their houses were bought from developers. Data of other attributes were collected through observation and measurement. The measurement of road width was done by using measuring tape while measurement of the distance between homes to CBD was helped by Google Map. All data of respondents' housing attributes are ratio scale, except availability of public green space which is nominal scale data (in form of category) [15]. The category is whether it is available or not. For example, the score is one (1) if greening site is available in housing and the score is zero (0) if public green space is unavailable. That is called dummy variables as well. Housing price was converted into Rupiah (Indonesian currency) when this research was conducted (2016). This is due to the difference value of money during 2011-2015. All the price of respondents' house are converted by using average of Indonesia's inflations in 20112015 for expense of a house according to the Consumer Price Index (IHK) 2011 [15], 2012 [16], 2013 [17], 2014 [18], and 2015 [19]. After all data were obtained, multiple linear regression technique was used to analyze the data.

\section{ANALYSIS AND RESULT}

\subsection{General Description of Research Variables}

The average of the building width of middle class housing in this research is $43.2 \mathrm{~m}^{2}$. The width of the largest building is $70 \mathrm{~m} 2$ and the smallest one is $36 \mathrm{~m}^{2}$ (see Table 2).

The houses observed have at least 2 rooms, and 3 rooms at the most; and have at least 1 bathroom and 2 bathrooms at the most (see Table 2).

Of all the housings that were observed, not all of them provide public green space. There are only $62.5 \%$ housings which provide some, as seen in Table 3.

The average road width in housing studied in this research is $6.4 \mathrm{~m}$. The widest road is $10 \mathrm{~m}$ and the narrowest road is 3.8 $\mathrm{m}$. The average distance to Central Business District (CBD) is $4.689 \mathrm{~km}$. The furthest distance to CBD is $8.8 \mathrm{~km}$ that is from Puri Gunung Anyar Regency to CBD. The nearest distance to $\mathrm{CBD}$ is $2 \mathrm{~km}$ that is from Gunung Anyar Permai Regency to CBD. 
Table 2 Statistic of 6 Independent Variables

\begin{tabular}{|l|c|c|c|c|c|}
\hline \multicolumn{1}{|c|}{ Variable } & Number & Min & Max & Mean & Std. Dev \\
\hline Building width & 100 & $36 \mathrm{~m} 2$ & $73 \mathrm{~m} 2$ & $42.52 \mathrm{~m} 2$ & 7.01 \\
\hline Amount of room & 100 & 2 unit & 3 unit & 2.07 unit & 0.26 unit \\
\hline Amount of bathroom & 100 & 1 unit & 2 unit & 1.11 unit & 0.31 unit \\
\hline $\begin{array}{l}\text { Road Width in front } \\
\text { of home }\end{array}$ & 100 & $3.8 \mathrm{~m}$ & $10 \mathrm{~m}$ & $6.43 \mathrm{~m}$ & $1.6 \mathrm{~m}$ \\
\hline Distance to CBD & 100 & $2 \mathrm{~m}$ & $8.8 \mathrm{~m}$ & $4.82 \mathrm{~m}$ & $2.09 \mathrm{~m}$ \\
\hline $\begin{array}{l}\text { Distance to education } \\
\text { facilities }\end{array}$ & 100 & $0.3 \mathrm{~m}$ & $2.5 \mathrm{~m}$ & $1.54 \mathrm{~m}$ & $0.68 \mathrm{~m}$ \\
\hline
\end{tabular}

Table 3 Statistic of Availability of Greening Sites

\begin{tabular}{|c|c|c|}
\hline Variable & Frequency & $\%$ \\
\hline \multicolumn{3}{|l|}{$\begin{array}{l}\text { Availability of } \\
\text { greening sites }\end{array}$} \\
\hline Unavailable (score 0$)$ & 3 & 37.50 \\
\hline Available (score 1) & 5 & 62.50 \\
\hline Total & 8 & 100.00 \\
\hline
\end{tabular}

There were some changes in variable "distance from home to $\mathrm{CBD}$ " for some middle class housing in East Surabaya during 2011-2015. It was influenced by the opening access of MERR IIC, and several developments constructed around the street. For example is the case of Green Lake Regency. Before 2013, the nearest CBD from that housing to CBD was Jalan Prapen, around $6.6 \mathrm{~km}$. For information, MERR IIC was still under construction along 2011, and the street was open in early 2012. At that time, MERR IIC was not the CBD because its neighborhood was still under development as new business centers. In 2013, various business centers emerged such as Central Business Park Semampir, Semampir Shophouse, etc. Therefore, in 2013, MERR IIC became the nearest CBD for Green Lake Regency (about 3.4 km away).

The average distance from home to education facilities is $1.5 \mathrm{~km}$. The furthest is $2.5 \mathrm{~km}$ (Puri Gunung Anyar Regency), and the nearest is $0.27 \mathrm{~km}$ (Pesona Alam Gunung Anyar).

Table 4 Dependent Variable - Housing Prices

\begin{tabular}{|c|c|r|r|r|r|}
\hline Variable & Number & $\begin{array}{c}\text { Min } \\
\text { (Rp-Mil) }\end{array}$ & $\begin{array}{c}\text { Max } \\
\text { (Rp-Mil) }\end{array}$ & $\begin{array}{c}\text { Mean } \\
\text { (Rp-Mil) }\end{array}$ & $\begin{array}{c}\text { Std. Dev } \\
\text { (Rp-Mil) }\end{array}$ \\
\hline Housing prices & 100 & 257.80 & 917.93 & 436.94 & 115.08 \\
\hline
\end{tabular}

The average price of middle class housing in East Surabaya is $\operatorname{Rp} 436,940,000.00$. The highest price is $\mathrm{Rp} 917,930,000.00$, that is Green Lake, and the lowest price is Rp 257,800,000.00 that is Citra Medayu Regency. The statistics of housing prices as dependent variable can be seen in Table 4.

\subsection{Classic Assumption Test}

The first thing to do before running the multiple analysis regression, classic assumption test which contains of normality test, heteroskedasticity test, multicollinearity test, autocorrelation test must be conducted. It is done to make sure that multiple linear regression model is BLUE (best linear unbiased estimator).

The respondents' data in this research are determined as normal distributive based on Kolmogorov Smirnov Test (normality test) as the significance value is $0.463>0.05$. It was also found that the respondent data do not contain any heteroskesdasticity, given that the significance value of Rank Spearman's correlation for all independent variables are $>0.05$.

The respondent's data do not contain multicollinearity within dependent variables as all the VIF value $<10$. They also do not contain autocorrelation as the Durbin Watson value is 2.023 which is between dU (1.83) and 4-dU (2.17).

By the result of classic assumption tests, it is determined that the data used in this research fulfill all the assumptions needed. Therefore, multiple regression analysis can be done.

\subsection{Multiple Regression Analysis}

Table 5 shows the $\mathrm{F}$ Test results significance value of 0.000 $<0.05$. It concludes that all seven independent variables simultaneously have significant influences on the price of middle class housings in East Surabaya. While Table 6 shows the seven attributes of house in this research simultaneously influence 0.809 or $80.9 \%$ on the price of middle class housings in East Surabaya.

Table 5. Simultant Influence Test (F Test)

\begin{tabular}{|c|c|c|c|c|c|}
\hline Model & Sum of Squares & df & Mean Square & $\begin{array}{c}\text { F } \\
\text { Value }\end{array}$ & Sig. \\
\hline Regression & 1060664804076180000.00 & 7 & 151523543439454000.00 & & \\
\cline { 1 - 5 } Residual & 250484340387816000.00 & 92 & 2722655873780610.00 & 55.653 & 0 \\
\hline Total & 1311149144463990000.00 & 99 & & & \\
\hline
\end{tabular}

Table 6. R Square
\begin{tabular}{|c|c|}
\hline R & R Square \\
\hline 0.899 & 0.809 \\
\hline
\end{tabular}

Table 7, which is t-Test table, shows that all attributes have significance value $<0.05$. It means that all of housing attributes in this research significantly influence the housing price.

Table 7. Partial Influence Test (t-Test)

\begin{tabular}{|c|r|r|r|r|r|}
\hline \multirow{2}{*}{ Model } & \multicolumn{2}{|c|}{$\begin{array}{c}\text { Unstandardized } \\
\text { Coefficients }\end{array}$} & $\begin{array}{c}\text { Standar } \\
\text { dized }\end{array}$ & \multirow{2}{*}{ t } & \multirow{2}{*}{ Sig. } \\
\cline { 2 - 5 } & \multicolumn{1}{c|}{ B } & \multicolumn{1}{c|}{ S.E } & \multicolumn{1}{c|}{ Beta } & & \\
\hline (Constant) & $-337,386,336.85$ & $55,607,598.27$ & & -6.067 & 0 \\
\hline Building Width & $5,070,935.50$ & $927,541.10$ & 0.309 & 5.467 & 0 \\
\hline Amount of Room & $195,116,606.27$ & $28,324,445.32$ & 0.435 & 6.889 & 0 \\
\hline Amount of Bathroom & $65,337,092.43$ & $22,890,732.37$ & 0.179 & 2.854 & 0.005 \\
\hline $\begin{array}{c}\text { Availability of } \\
\text { greening sites }\end{array}$ & $56,493,577.72$ & $13,477,826.24$ & 0.214 & 4.192 & 0 \\
\hline $\begin{array}{c}\text { Road Width in front } \\
\text { of Home }\end{array}$ & $8,458,887.15$ & $3,979,332.23$ & 0.118 & 2.126 & 0.036 \\
\hline Distance to CBD & $-14,846,250.96$ & $2,593,806.23$ & -0.269 & -5.724 & 0 \\
\hline $\begin{array}{c}\text { Distance to } \\
\text { Education Facilities }\end{array}$ & $37,172,333.69$ & $8,041,076.29$ & 0.22 & 4.623 & 0 \\
\hline
\end{tabular}

In addition, through t-Test (see Table 7), it is able to derivate multiple regression equation as written below:

Housing Price $(\mathrm{Y})=-337,386,336.85+5,070,935.50 \mathrm{X} 1+$ $195,116,606.27 \mathrm{X} 2+65,337,092.43 \mathrm{X} 3+56,493,577.72 \mathrm{X} 4+$ $8,458,887.15$ X5 - 14,846,250.96 X6 + 37,172,333.69 X7

While $\mathrm{X} 1$ is building width, $\mathrm{X} 2$ is amount of rooms, $\mathrm{X} 3$ is amount of bathroom, X4 is availability of public green space, $\mathrm{X} 5$ is road width in front of house, X6 is distance to CBD, and $\mathrm{X} 7$ is distance to education facilities.

Using multiple regression equation above, the changes of housing price can be predicted when there are changes in every housing attributes. In other words, multiple regression equation can be used to identify implicit price [3] of each house attribute as the result below: 
1.Every $1 \mathrm{~m}^{2}$ additional width of building adds Rp5,070,935.50 to the housing price (no change at other attributes). It may be influenced by the majority of housing occupants' number and standard of space needed for housing for each $\mathrm{m}^{2}$ per each occupant. Most respondents need additional space so that they are willing to pay relatively expensive price for additional building width.

2. Every one additional room adds Rp195,116,606.27 of housing price (no change at other attributes). Households need more rooms and they are willing to pay relatively expensive price for extra room, due to particular condition (couple of growing children, or there is maid).

3. Every one additional bathroom adds Rp65,337,092.43 of housing price (no change at other attributes). It probably because extra bathrooms are frequently needed, especially, some members of household need bathroom simultaneously.

4. Every house located in housings which have public green space has higher price worth Rp56,493,577.72 than others which do not have public green space (no change at other attributes). It probably because the public green space can be used as garden and park for little children. As known that most of the respondents in this research are young couples (51\%) with age ranges from 26-35 years old.

5. Every $1 \mathrm{~m}$ additional width of road in front of house adds Rp8,458,887.15 of housing price (no change at other attributes). It is probably because of easy access needed for transportation or vehicle access. Based on the observation, most of the respondents have cars.

6. The houses are cheaper worth Rp14,846,250.96 than others for every $1 \mathrm{~km}$ further away to CBD (no change at other attributes). It is because the further distance to CBD, the more cost and longer time needed. Conversely, the nearer distance to $\mathrm{CBD}$, the less cost and time needed.

7. The houses are cheaper by Rp37,172,333.69 than others for every $1 \mathrm{~km}$ nearer away to education facilities such as schools (no change at other attributes). It is probably influenced by traffic jam that happens frequently on way to school and home time, the probability of lower quality, and bad student's attitudes of some educational facilities in East Surabaya.

\section{CONCLUSION AND DISCUSSION}

This research shows that all seven housing attributes observed in this research have influence on the price of middle class housing in East Surabaya either simultaneously or partially. As partially, all of those attributes have significant influences toward the middle housing price in East Surabaya.

Seven attributes are divided into two groups based on characteristics of their influences on the housing price; that is positive influence (building width, amount of rooms, and amount of bathrooms, availability of public green space, road width in housing, and distance from home to education facilities) and negative influence (distance from home to CBD)

It is found that implicit price [3] in each housing attribute is constant, whereby every change of value of housing attributes will affect the housing price constantly according to the implicit price of the housing attributes (in condition when an attribute change, the others do not).

In future, it needs a further study to analyze the influences of attributes distance from home to education facilities toward housing price. It was found in this research that those attributes have different influences toward housing price compared to previous researches or experts' opinion. Generally, the nearer distance from house to the education facilities, the higher price of the house will be. However, this research shows that the nearer house to the education facilities, the lower price of the house. This may indicate that the attribute is conditional; the influence toward housing price depends on the condition and research setting characteristics.

\section{REFERENCES}

[1] Bank Indonesia. (2013). Survei Harga Properti Residensial. Jakarta: Bank Indonesia.

[2] Michela Scatigna, Robert Szemere, Kostas Tsatsaronis. (2014). Residential Property Price Statistics Across the Globe. Swiss: Bank for International Settlements.

[3] DiPasquale, Denise, \& Wheaton, William C. (1996). Urban Economics and Real Estate Markets. New Jersey: Prentice-Hall.

[4] Wen, Haizhen, Zhang, Yan, \& Zhang, Ling. (2014). Do Educational Facilities Affect Housing Price? An Empirical Study in Hangzhou, China. Journal Habitat International, Vol. 42, pp. 155-163

[5] McDonald, John F., \& McMillen, Daniel P. (2007). Urban Economics and Real Estate. Victoria, Australia: Blackwell Publishing.

[6] Rahadia, Raden Aswin, Wiryonoa, Sudarso Kaderi, Koesrindartotoa, Deddy P., \& Syamwil, Indra Budiman. (2013). Attributes Influencing Housing Product Value and Price in Jakarta Metropolitan Region. Social and Behavioral Sciences, Vol. 101, pp. 368 - 378.

[7] Cebula, Richard J. (2009). The Hedonic Pricing Model Applied to the Housing Market of the City of Savannah and Its Savannah Historic Landmark District. The Review of Regional Studies, Vol. 39, pp. 9 - 22.

[8] Ottensmann, John R., Paytona, Seth, \& Man, Joyce. (2008). Urban Location and Housing Prices within a Hedonic Model. Regional Analysis \& Policy, Vol. 38 (1), pp. 19 - 35.

[9] Bayuprima, I GD Raka Natha. (2015). Pengaruh Ketersediaan Fasilitas Umum terhadap Harga Jual Perumahan di Kawasan Mangupura. (Magister), Universitas Udayana, Denpasar.

[10] Asmawi, M. Zainora, Noor, Norzailawati Mohd, Manzahari, Mohd Nasrul Hanis, \& Abdullah4, Alias. (2014). The Relationship between Open Spaces and House Prices in Selected Townships in Kuala Lumpur, Malaysia. Paper presented at the International Conference on Social Sciences and Humanities, Istanbul, Turkey.

[11] Sidik, Machfud. (2000). Model Penilaian Properti Berbagai Penggunaan Tanah di Indonesia. Jakarta: Perpustakaan Nasional.

[12] Hidayati, Wahyu, \& Harjanto, Budi. (2003). Konsep Dasar Penilaian Properti (Vol. 1). Yogyakarta: BPFE-Yogyakarta.

[13] Guntoro, Lily Lucia. (2011). Pengaruh Green Development terhadap Harga Pasar Perumahan Kelas Menengah Bawah Surabaya Barat. (Magister), Institut Teknologi Sepuluh Nopember, Surabaya.

[14] Julious, Steven A. (2010). Sample Sizes for Clinical Trials. New York: CRC Press.

[15] Badan Pusat Statistik (BPS) Jawa Timur. 2012. Indeks Harga Konsumen 7 Kota di Jawa Timur 2011. Surabaya: Penerbit BPS Jawa Timur.

[16] Badan Pusat Statistik (BPS) Jawa Timur. 2013. Indeks Harga Konsumen 7 Kota di Jawa Timur Tahun 2013. Surabaya: Penerbit BPS Jawa Timur.

[17] Badan Pusat Statistik (BPS) Jawa Timur. 2014. Indeks Harga Konsumen 7 Kota di Jawa Timur Tahun 2014. Surabaya: Penerbit BPS Jawa Timur.

[18] Badan Pusat Statistik (BPS) Jawa Timur. 2015. Indeks Harga Konsumen 8 Kota di Jawa Timur Tahun 2015. Surabaya: Penerbit BPS Jawa Timur.

[19] Badan Pusat Statistik (BPS) Jawa Timur. 2016. Indeks Harga Konsumen 8 Kota di Jawa Timur Tahun 2016. Surabaya: Penerbit BPS Jawa Timur. 